\title{
Diffusion Weighted Magnetic Resonance Imaging in Cerebral Fat Embolism
}

\author{
Serebral Yă̆g Embolisinde Difüzyon A ğırlıklı Manyetik Rezonans Görüntüleme
}

Feride Kural, Fuldem Yıldırım Dönmez, Hülya Aslan, Burcu Akpınar, Ahmet Muhteşem Ağıldere

Baskent University, Medical Faculty Department of Radiology, Ankara, Turkey

\begin{abstract}
Summary
Fat embolism syndrome (FES) is primarily associated with long bone fractures of the lower extremities. FES typically occurs between 1 and 3 days after the trauma, and the clinical triad is hypoxia, neurologic symptoms and petechial rash. Neurologic symptoms vary widely from confusion to coma, and in rare instances death may occur. Magnetic resonance imaging is the most effective method used to diagnose cerebral FES. Typical findings are multiple punctate hyperintensities in the subcortical and deep white matter on T2 weighted and diffusion-weighted images. This is known as a starfield pattern. This paper discusses a case of cerebral FES in a patient who had neurologic symptoms after traumatic femur neck facture. (Turkish Journal of Neurology 2012; 18:108-10)
\end{abstract}

Key Words: Fat embolism, diffusion, MRI

\section{Özet}

Yağ embolisi sendromu genellikle alt ekstremitenin uzun kemiklerinin fraktürü veya ortopedik cerrahi sonrası ortaya çıkan ciddi ve hayatı tehdit eden bir tablodur. Travmayı takiben 1-3. gün içinde ortaya çıkar. Klinik triadı hipoksi, nörolojik semptomlar ve peteşiyel raştır. Nörolojik semptomlar konfüzyondan komaya kadar değişebilir; nadir vakalarda ölümle sonuçlanabilir. Serebral yağ embolisi sendromunun tanısında en duyarlı yöntemin MRG olduğu gösterilmiştir; tipik bulgular T2 ağırlıkl görüntülerde ve difüzyon ağılıklı görüntülemede subkortikal ve derin beyaz cevherde multipl, punktat hiperintensitelerdir. Bu yazıda travmatik femur fraktürü sonrasında nörolojik bulguları gelişen olgunun difüzyon ağırlıklı manyetik rezonans görüntüleri sunulmaktadır. (Türk Nöroloji Dergisi 2012; 18:108-10)

Anahtar Kelimeler: Yağ embolisi, difüzyon, manyetik rezonans görüntüleme

\section{Introduction}

Fat embolism syndrome (FES) is primarily associated with long bone fractures of the lower extremities (1-3). The frequency of FES is in the range of $0,5 \%$ to $3,5 \%(1,4,5)$. FES typically occurs between 1 and 3 days after the trauma, and the clinical triad is hypoxia, neurologic symptoms and petechial rash $(4,5)$. Neurologic symptoms vary widely from confusion to coma, and in rare instances death may occur. Mortality incidence increases with the severity of pulmonary and neurologic injury $(2,5,7)$. Cerebral FES is generally self-limiting and in most cases neurologic function is recovered in a period lasting from a few days to several months. Magnetic resonance imaging is the most effective method used to diagnose cerebral FES. Typical findings are multiple punctate hyperintensities in the subcortical and deep white matter on T2 weighted and diffusion weighted images. This is called a starfield pattern $(3,5,7-9)$.

This paper discusses a case of cerebral FES in a patient who had neurologic symptoms after a traumatic femur neck fracture.

Address for Correspondence/Yazışma Adresi: Feride Kural MD, Baskent University, Medical Faculty Department of Radiology, Ankara, Turkey Phone.: +90 031221268 68-14378 E-posta: drkural@hotmail.com

Received/Gelis Tarihi: 25.01.2012 Accepted/Kabul Tarihi: 23.07 .2012 


\section{Case Report}

A previously healthy 47 year-old woman suffered a fall and arrived at the emergency room with left hip and leg pain. Her examination showed a femur neck fracture. The left leg was immobilized and there was no evidence of head injury. She was fully conscious with stable respiratory and vital status. The patient was taken to the operating room for a total hip prosthesis and then to the surgical intensive care unit., The patient became confused in the post-operative period and was unresponsive to verbal stimuli. A brain MRI was then performed and T1 and T2 weighted images were normal. However, on FLAIR images a few hyperintense foci in the periventricular white matter and centrum semiovale were found (Figures $1 \mathrm{a}, 1 \mathrm{~b}$ ). There were no signal abnormalities in the gray matter or posterior fossa, and there was no evidence of intracranial hemorrhage. On the diffusion-weighted images (DWI) $(b=1000)$ there were multiple lesions in the peri-ventricular region and centrum semiovale, which appeared as hyperintense dots on a dark background (Figures 2a,2b) and hypointense on ADC maps (Figures $3 \mathrm{a}, 3 \mathrm{~b}$ ). No dermatologic or respiratory abnormalities were found and the echocardiogram was normal. According to the brain MRI findings, considering the normal preoperative neurologic status and rapid neurologic symptoms after surgery, a diagnosis of cerebral FES was suggested. Eight days after surgery the patient's neurological status had improved and she was discharged. The one month follow up showed there was no residual neurologic deficit.

\section{Discussion}

The major and minor findings of FES were defined by Gurd. The major triad is hypoxia, neurologic symptoms and petechial rash. The minor findings are tachycardia, fever, anemia, and thrombocytopenia $(2,4,10)$. Respiratory symptoms which occur before the neurologic symptoms include hypoxia, tachypnea, and dyspnea. Cutaneus findings which appear within 12-36 hours are reddish non-palpable petechial rash covering neck, arms, and chest. Neurologic symptoms are nonspecific and may include headache, confusion, decreased conciousness level, coma and seizures. The treatment of FES is supportive and prophylactic.

There are several theories about the etiology of FES. Fat emboli, which enter the venous circulation and travel to the pulmonary vasculature, can cause occlusion of pulmonary capilleries $(11,12)$. Free fatty acids (FFAs) are released from fat emboli and are hydrolyzed by lipoprotein lipase to toxic intermediates, which damage capillary endothelium aggravating alveolar edema.

Neurologic symptoms occur because of the occlusion of cerebral blood vessels by fat emboli, impairment of blood brain barrier by FFAs, or obstruction due to the change in the resolution of fat in blood (13-16). White matter involvement and symmetric appearance of the lesions suggest that emboli is the possible cause of the neurologic symptoms (3).

Cerebral CT scans are generaly normal though diffuse edema with scattered hypodense areas or hemorrhage can be seen. MR imaging is more sensitive of finding cerebral FES which is present as multiple small nodular or patchy hyperintense lesions in the periventricular, subcortical white matter and centrum semiovale on T2 weighted images. The characteristic starfield pattern of restricted diffusion is also seen on DWI as part of the multiple hyperintense foci against dark white matter back

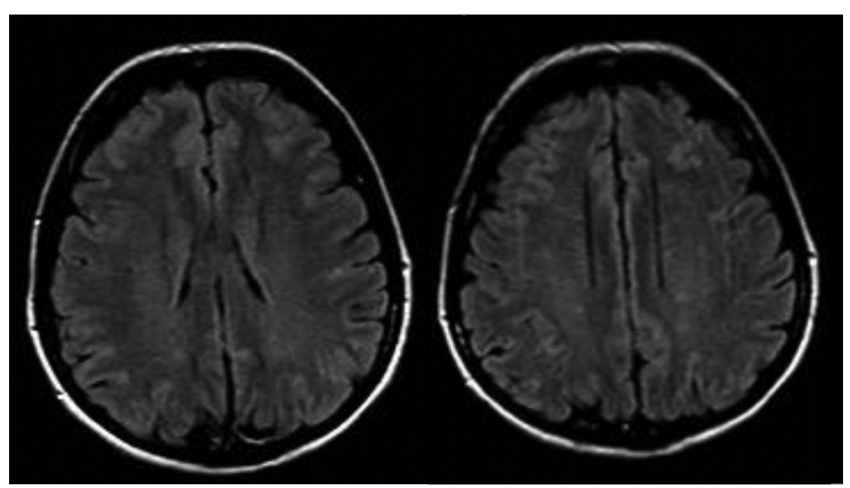

Figure 1a-b. FLAIR images showing a few hyperintense foci in the periventricular white matter and centrum semiovale.

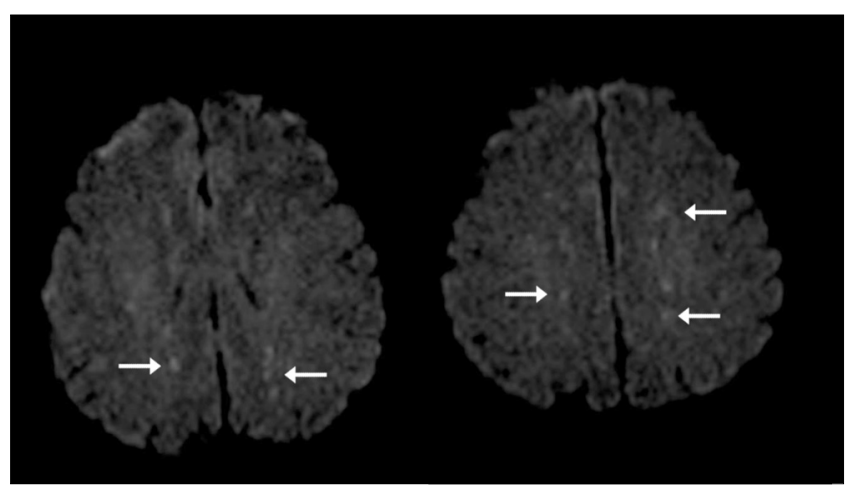

Figure 2a-b. DWI $(b=1000)$ showing multiple hyperintense lesions in the periventricular white matter and centrum semiovale on a dark white matter background revealing a starfield pattern.

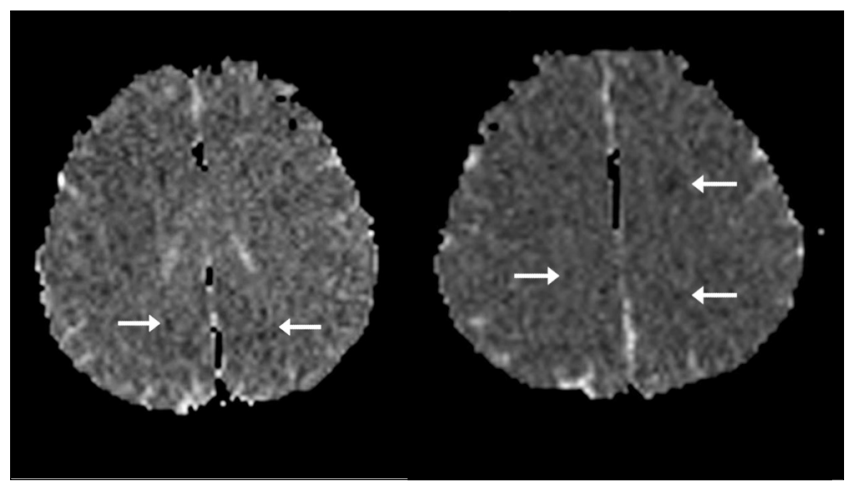

Figure 3a-b. Axial apparent diffusion coefficient (ADC) map demonstrating low signal intensity of the lesions. 
ground $(8,9)$. The DWI findings may maintain an early and sensitive diagnosis of cerebral FES which responds to the hyperacute cytotoxic edema related with ischemia. Hyperacute cerebral FES enhancement on T1 weighted post-contrast images can also be helpful in detecting the brain blood barrier dysfunction (6).

There are other MRI findings which show lesions similar to those found with FES, such as diffuse axonal injury (DAI), gliosis, toxic leukoencephalopathy, metabolic disorders, traumatic dissection and vasculitis. Cerebral FES can be diagnosed based on the clinical setting, such as when an initially normal neurologic examination is followed by sudden neurologic symptoms after a long bone fracture or orthopedic surgery through the use of DWI. Gliosis, toxic leukoencephalopathy and metabolic disorders show increased diffusion on a DWI scan. DAI occurs after the neurological findings of the initial examination. MRI hyperintense lesions on T2 weighted images illustrating the subcortical white matter, corpus callosum, internal capsule, basal ganglia and brainstem may show restricted diffusion.

In our case brain CT was normal. However, when brain MRI was performed, FLAIR images showed a few hyperintense foci in the periventricular white matter and centrum semiovale. DWI showed multiple hyperintense lesions in the periventricular white matter and centrum semiovale. These hyperintense lesions had restricted diffusion on DWI revealing a starfield pattern. The clinical presentation and DWI findings led to the diagnosis of cerebral FES. The patient was supportively managed and neurologic impairment was resolved without any complications in a month.

\section{Conclusion}

Cerebral FES should be considered in cases where neurologic symptoms suddenly appear after traumatic bone fractures, especially in patients with an initial period of normal mental status. The cranial CT may be normal. Cranial MRI may show hyperintense lesions in periventricular white matter and centrum semiovale, but DWI is the most efficacious technique available to confirm a diagnosis of cerebral FES.

\section{References}

1. Ryu CW, Lee DH, Kim TK, Kim SJ, Kim HS, Lee JH, et al. Cerebral fat embolism: diffusion-weighted magnetic resonance imaging findings. Acta Radiol. 2005;46:528-33.

2. Chen JJ, Ha JC, Mirvis SE. MR imaging of the brain in fat embolism syndrome. Emerg Radiol 2008;15:187-92.

3. Butteriss DJ, Mahad D, Soh C, Walls T, Weir D, Birchall D. Reversible cytotoxic cerebral edema in cerebral fat embolism. AJNR Am J Neurol 2006;27:620-3.

4. Gurd AR. Fat embolism: an aid to diagnosis. J Bone Joint Surg Br 1970;52:732-7.

5. Johnson MJ, Lucas GL. Fat embolism syndrome. Orthopedics 1996;19:41-8.

6. Simon AD, Ulmer JL, Strottmann JM. Contrast-enhanced MR imaging of cerebral fat embolism: case report and review of the literature. AJNR Am J Neuroradiol 2003;24:97-101.

7. Kim HJ, Lee CH, Lee SH, Moon TY. Magnetic resonance imaging and histologic findings of experimental cerebral fat embolism. Invest Radiol 2003;38:625-34.

8. Parizel PM, Demey HE, Veeckmans G, Verstreken F, Cras P, Jorens PG, et al. Early diagnosis of cerebral fat embolism syndrome by diffusion- weighted MRI (starfield pattern). Stroke 2011;32:2942-4.

9. Marshall GB, Heele VR, Herx L, Abdeen A, Mrkonjic L, Sevick RJ, et al. Magnetic resonance diffusion weighted imaging in cerebral fat embolism: case report and review of the literature. AJNR Am J Neurol 2003;24:97-101.

10. Eriksson EA, Schultz SE, Cohle SD, Post KW. Cerebral fat embolism without intracardiac shunt: A novel presentation. J Emerg Trauma Shock 2011;4:309-12.

11. Levy D. The fat embolism syndrome. A review. Clin Orthop Relat Res 1990;261:281-6.

12. Habashi NM, Andrews PL, Scalea TM. Therapeutic aspects of fat embolism syndrome. Injury 2006;37(Suppl 4):68-73.

13. Drew PA, Smith E, Thomas PD. Fat distribution and changes in the blood brain barrier in a rat model of cerebral arterial fat embolism. J Neurol Sci 1998;156:138-43.

14. Gossling HR, Pellegrini VD Jr. Fat embolism syndrome: a review of the pathophysiology and physiological basis of treatment. Clin Orthop Relat Res 1982;165:68-82.

15. Kim HJ, Lee CH, Lee SH, Cho BM, Kim HK, Park BR, et al. Early development of vasogenic edema in experimental cerebral fat embolism in cats: correlation with MRI and electron microscopic findings. Invest Radiol 2001;36:460-9.

16. Oh WH, Mital MA. Fat embolism: current concepts of pathogenesis, diagnosis, and treatment. Orthop Clin North Am 1978;9:769-79. 